Praveen Shetty

M.I.T. Manipal University, Manipal, Karnataka Vishnumoorthy Prabhu

Government Women's College, Udupi, Karnataka

Pratapchandra T

Government P U College, Hiriyadka, Udupi, Karnataka

\title{
Changing Notes in the Voices beyond the Rooster Coop: A Neo-Capitalist Coup in Aravind Adiga's The White Tiger
}

\section{ABSTRACT}

Aravind Adiga's novel The White Tiger encapsulates the complexities of identity formation in a milieu effected by neo-capitalism. The novel, for many, is about a new identity made available to the hitherto marginalized in the form of opportunities unveiled by market forces. It is also perceived as a registration of the frustration and anger of the deprived that has become conscious of the new possibilities. Understandably, interpreting the novel on these lines leads to the identification of the protagonist Balram as a champion of the marginalized, settling scores with the oppressive system. However, there are far subtler notes in the protagonist's attitude to these sweeping changes than the simple and one dimensional approach of an achiever who is able to break the "rooster coop" and revel at the reversal of fortune. Neither is it a representative voice of the suppressed class turning the table on its oppressor by using the opportunities offered by the global market. The "notes" of the voices that emerge as Balram, the boy from darkness, moves up the ladder to become Ashok Sharma, the entrepreneur hiding in light, not only lack symphony but also create a distinct dissonance. Clearly, the discord in the changing notes is brought about by the forces that changed the world he lives in-a neo-capitalist world. The whole process of Balram turning into Ashok Sharma is a neocapitalist coup. 
In India it always used to be that if you were poor and someone else was incredibly rich, that was just a fact of life. In fact, even though much of India has always been poor, there was very little crime. But now the old bonds of community, caste and family are fraying. The temptations before a poor person are greater. You are suddenly aware of shopping malls, there are advertisements everywhere, and you see your neighbours doing better than you. This leads to frustration and frustration to anger. (qtd. in Ceaser)

These words of Aravind Adiga, the author of The White Tiger, seemingly sum up the idea that the protagonist of the novel represents. The novel is about a changed world where liberal capitalism has brought about a change in the lives of the people who used to have a conservative life style. However, the anger takes a different dimension altogether in The White Tiger through the protagonist, Balram Halwai. Under the apparent guise of a struggle to move up against an oppressive system, "the white tiger" represents a complex attitude to life. Ironically, in trying to move up the ladder by taking advantage of new opportunities and openings, the protagonist fails to be a plain champion of the marginalized as encapsulated in the words of the author (as quoted above). In fact, Balram seems to be an agent of the new forces of neo-capitalism driven by veiled self-interest and executed with utter sophistication. The struggle of the protagonist is not the simple struggle of a poor man trying to move up the social ladder whilst fighting against the upper class, but it is the struggle of his real self coming to terms with his projected persona that finds a different place in the changed world.

Adiga's novel is an apparent attempt to show the "frustration," "anger," and response of the marginalized to a globalized world that places in unprecedented proximity the rich and the poor, and the opportunities to transgress between these. Further, the autobiographical narration of the novel is so planned by the author that it places the protagonist Balram in the position of interpreter and analyst of all events and characters. This, in fact, convincingly corresponds to the author's statement quoted earlier. Balram is offered the role of a "deviant" element, forcing himself out of the rooster coop. He is also given a voice to present himself in the vanguard of the "oppressed" and "victimized section," and yet, to stand apart from that as "a thinking man" who is capable of intellectual manipulation typical to the other section. This interplay of voices between the narrator and the inner self runs through the novel, defying a simple one-dimensional reading of it as that of class struggle. 
It is true that the novel offers an exposé of an India breaking out into the world of late capitalism-aggressive, brash, cynical, driven (Taras). It tells the story of Balram, an otherwise nondescript young villager of lower caste-his jati is of pastry makers-who arrives in Delhi and is soon hired to be a chauffeur who would capitalize on the opportunities offered by the transformed social set-up. In the economic pandemonium of present-day India with its call centres, high-tech areas, and sprawling shopping malls, Balram can aspire to even more upward social mobility. Picking up the cues he is exposed to from the business class and the government officials tied in with it, Balram decides that crime and dishonesty pay handsome rewards (Taras). The rags-to-riches trajectory takes him to Bangalore where he finds himself in a changed world that needs him to assume a different identity for the world.

Apparently, the story seems to suggest the idea that in a transformed world, a truly smart man can reach the top if he no longer limits himself to his low class or the "rooster coop" as the narrator refers to it. Balram does emerge as one of these smart men able to escape the rooster coop. Further, he seems to represent the idea of a suppressed class trying to settle its score with the oppressor using the changed circumstances. Balram's transformation from an uncouth, dirty but honest driver to a polished, shrewd and manipulating entrepreneur involves a reversal of the master-servant relationship. However, he represents more than plain smartness exhibited in the face of changed circumstances. In fact, he embodies a number of other traits that neo-capitalism brought to a conservative society.

Ideally, class struggle would expect itself to culminate in an egalitarian set-up. It is not about a mere inversion of power structure, but about attaining a justified distribution of resources. The seeming class struggle, culminating in Balram's emergence as its voice, does appear to realize such an egalitarian set-up. One could easily mistake that

It is the India of Darkness which is focused by the novelist, articulating the voice of the silent majority, trying to dismantle the discrimination between the Big Bellies and the Small Bellies and create a society based on the principle of equality and justice. Balram Halwai, the protagonist is a typical voice of underclass ... and struggling to set free from age old slavery and exploitation. (Singh 98)

In fact, Balram, the narrator, tries his best to retain this image of a class representative through his manipulative narration of his story. The assertion of Balram that white men will be finished soon and "in 20 years time it will just be us brown and yellow men at the top of the pyramid, and we'll rule the world" (Adiga 305) seemingly sounds like the voice of an excited emergent section. It does seem to represent the emergence of that much- 
heralded economic powerhouse, the "new India” (Mattin). Thus, Balram's story is a quasi celebration of the merger of the margins with the centressocially and economically, locally and globally. The difference, though, is that Balram's new India is made up of individuals fighting for their spaces rather than a class fighting for its space.

The most striking of all that Balram stands for is his self-interest in everything he does. From the very beginning he exhibits characteristic traits not typical to his "small-bellied" community. Driven by an entrepreneurial desire to be more than what he is and what his community expects him to be, Balram expresses his desire to be "a driver." Unlike a traditional society which would not only scorn but also suppress this preference, the changed society gives him an opportunity to learn the skill that "only a boy from warrior caste can manage" (Adiga 56). It takes three hundred rupees plus a bonus and "coal was taught to make ice"-a reference that indicates the fact that money can create opportunities. However, Balram can do this only at the mercy of his grandmother Kusum, who epitomizes the conservative society. Kusum's reluctant acceptance of Balram's unusual desire indicates a crack in the system and the crack is only going to widen. Yet, this fissure in the system is understandable and acceptable since it is indispensable for the voice of the peripheral communities to be hearda status quo can only seal their marginality. However, here the force that is causing the crack is "self-interest" - a trait that is alien to the traditional society and that has no consideration for the values of the traditional society. The mismatch between Balram's ready acceptance to "swear by all the gods in heaven" (Adiga 56) that he would not forget his granny once he became rich, and the reality after is proof enough to note the all pervading presence of self-interest in the changing world. The same self-interest propels Balram to create a series of falsehoods and pretend to possess the very values he despises in order to get the job of a driver. His words "I have got four years experience. My Master recently died, so I-”" (Adiga 60) hint at a lack of scruples in the name of "moving up the ladder." Again, his act of loyalty when he dives at the Stork's feet is totally orchestrated:

You should have seen me that day-what a performance of wails and kisses and tears! You'd think I'd been born into a cast of performing actors! And all the time while clutching the Stork's feet I was staring at his huge, dirty, uncut toe nails, and thinking ... why isn't he back home screwing poor fishermen of their money and humping their daughters? (Adiga 61)

These instances involving Balram, the one trying to escape the coop, have within them the seeds of shrewdness that is not expected among the "coop" but is fitting in the world of the entrepreneurs. It is the articulation of the 
narrator Ashok Sharma that makes the acts of the narrator Balram convincing through the logic of a different world. Ironically, Ashok Sharma believes that his conscious acts of "meekness" and "submission" as Balram in the past are traits of smartness on the part of one of the marginalized.

Contrary to the overt idea of a suppressed class trying to retaliate using the powers bestowed by the new economic forces, the story of Balram strikes a rather complex note. It is not the story of a revolt against the oppressor with a concrete class consciousness but rather a story that makes use of class consciousness for an individual gain. Balram's projection that he is a boy from Laxmangarh and from darkness serves him well in the Stork's family. Ashok, his master whom Balram eventually murders on his path to liberation, retains him as the driver against the wishes of his wife and brother on the basis of his image as a boy from Laxmangarh: "We don't know who is who in Delhi. This fellow, we can trust him. He is from home" (Adiga 122). In fact, Balram maximizes this to his advantage when needed. For instance, in trying to get the job of a driver, Balram makes the most of his "boy from Laxmangarh" image. He even tries to placate Stork by flattering him: "Of course Sir-people say 'Our father is gone, Thakur Ramdev is gone, the best of the landlords is gone, who will protect us now?'” (Adiga 61). However, the same Balram does not care about what would happen to his "home" once his act of murder is known in Laxmangarh. His attempt at liberation is not the one that emancipates his people in the darkness; instead it is one that leaves the darkness behind. Balram knows exactly, long before he murders Ashok, what the consequences of his actions will be as he narrates the incident about Buffalo's son's kidnap: "Now who would want this to happen to his family sir? Which inhuman wretch of a monster would consign his own granny and brother and aunt and nephews and nieces to death? The Stork and his sons could count on my loyalty" (Adiga 67). Yet, he chooses to be the very same inhuman wretch of a monster in his final act of transgression.

At the same time, Balram tries to present the "anger" of his class against the master class as a justification for his acts with personal motives. His act of entering the shopping mall, driving the Honda City all for himself with $\mathrm{A} / \mathrm{C}$ on, hooting the horn each time he saw a pretty girl, and spitting over the seats of the Honda City might be symbolic representations of a class giving vent to its frustration against the oppressor. Even the words of Balram, "The strangest thing was that each time, I looked at the cash I had made by cheating him, instead of guilt what did I feel? Rage. The more I stole from him, the more I realized how much he had stolen from me" (Adiga 230), sound like a voice of the suppressed class. But the underlying fact is Balram, the narrator, uses class anger as a means to justify his personal acts. The drive to steal stems from a personal need (to be able 
to "dip the beak" into a golden haired woman), and not from his realization of how much his master had stolen from him. However, he seems to convince himself of the fairness of the act on the pretext of his realization of the injustice meted out to him. The narrator's insistence on his lack of remorse at the murder of his master on the ground that it was his way of achieving liberation from oppression- "I will say it was all worthwhile to know just for a day, just for an hour, just for a minute what it means not to be a servant" (Adiga 321)-lacks solidity as it ignores the fate of the darkness completely.

Whatever liberation Balram achieves is on an individualistic scale, and the class that he claims to represent remains marginal to his accomplishment. Of course, he succeeds in becoming the "Master" and takes care of his "servants," but he fails to move the people from darkness to light. In a changed environment he hides himself in the light and perpetuates a different kind of darkness around him. A successful Balram goes after things exactly the way his masters did: his obsession with chandeliers (he even fixed a chandelier in his toilet), luxury cars, hi-tech gadgets and getting whatever he wants by using whatever means required.

The individual who succeeds in breaking the rooster coop emerges with a set of traits alien to the coop he belonged to. This individual is not only a product of neo-capitalism but also a representative of it. $\mathrm{He}$ brings with him sophistication, dynamism, display, role play and a sense of extreme shrewdness. The sophistication which Balram Halwai exhibits all through his life in "moving up the ladder," and especially in writing to the Chinese Premier shows that he is not a naïve entrepreneur. In fact, he writes to the Chinese Premier not a mere success story, but a lesson of Smartness. Balram is so smug about his own smartness that he now considers it worth advertising that "lessons in life and entrepreneurship" are offered freely. Given the master-servant relationship at the "white tiger technology drivers," we notice that this advertisement of Balram is also a "display" which his new persona considers essential in the changed world. He is shrewd enough not to reveal any of his secrets to his servants. In fact, he regrets letting Asif know that he had paid off the family that lost a son in the accident. His lies, the manipulation of language, the eavesdropping, the alacrity with which he learnt to drive and the people management skills are in place in the new neo-capitalist system, which opens itself up for those who break the rooster coop. So much so that Balram now feels that the ploy of calling employees "family" is an insult. His changed value system can now see through the hollowness of the idea of "family" and he has no need to sustain it any longer. The Stork's continual reference to Balram being a member of the family and Balram's pretence of the same is essential for him to break the "coop." He needs to be an insider so that 
he can gain access to the desired information. It worked for him in his discussions with the Stork and his sons, in his relationship with Rampersad and finally in his dealings as Ashok. Balram uses this insider information to his advantage and emerges as an independent outsider with a different persona-Ashok Sharma. The new persona working in a new set-up has no need to call his servants "family" but they are his "employees" just like the employer is no longer a "master" but an "entrepreneur." This also removes the camouflage of kinship between the entrepreneur and his personnel that can shade any scheming against him.

Changes in social and institutional structures take place at a rapid speed in a neo-capitalist system. This brings about an alarming change in the very way of thinking. Subsequently, the old familial values are now replaced by individualistic and self-centred behavioural modes. The cities, the beacon of modern capitalism, germinate these changes which are not self-contained but spread to places like Laxmangarh and Dhanbad. Ashok, the landlord, changes his plans to return to America after two months' stay in India because he feels that "this place is going to be like America in ten years" (Adiga 89). Being a representative of the elite in the old world, he wants to have the best of both in the new India. He glibly expects the old values to continue in the new set-up:

We've got people to take care of us here-our drivers, our watchman, our masseurs. Where in New York will you find someone to bring you tea and sweet biscuits while you are still lying in bed, the way Rambahadur does for us? You know, he's been in my family for thirty years-we call him a servant but he's a part of the family. (Adiga 89)

But along with the changed system, these familial values also change or if they remain, they remain as a sly pretence for personal gain.

However, it works on a different plane in the case of an individual who belonged to the other side of society in the old world. New opportunities certainly allow the individual to have access to all that is denied hitherto, but they also place him in a fix in terms of opting between making the most of the opportunity for the self and continuing to be loyal to the "family." Individualistic drive continually struggles with the old familial values, and ultimately it is one's ability to hold onto the call of the self in the face of the disintegration of "family values" that makes him smart. When "the long whistle blew and the train headed off towards Dhanbad," Balram knew that this "broad shouldered, handsome, foreign educated" master was "completely unprotected by the usual instincts that run in the blood of a land lord" (Adiga 142). Balram thinks that "if you were back in Laxmangarh, we would have called you the Lamb” (Adiga 142). Balram 
capitalizes on these weaknesses of his master and eventually eliminates this hurdle in moving up, using the very traits in the master brought about by the new system as a means to attain a new persona in the system. The two parallel instances of road accidents reveal the divide between the old familial values and the new individualistic values. When the Stork's family tries to fix Balram in Pinky madam's hit and run case, the Stork says that Kusum was "so proud of you for doing this. She's agreed to be a witness to the confession as well" (Adiga 169). This is how a victim is converted into a hero- "the Indian family is the reason we are trapped and tied to the coop" (Adiga 176). It would take a "white tiger"-one "who is prepared to see his family destroyed-hunted, beaten and burned alive by the masters"- to "break out of the coop" (Adiga 176-77). The landlords feel it is natural to make use of a servant, Balram, to save their skin, while at a later stage, the same servant, who has become an entrepreneur, feels it is natural to use "money" to save his skin. When Asif, Balram's driver rams his Qualis into a boy on a bike, Balram does not get panicky. The first thing he asks him to do is to "call the police at once" (Adiga 306) and "to get these women home, first of all." Ashok Sharma alias Balram knows very well that he is in a different place where money provides one with choices.

Neo-capitalism's substitutions of traditional values extend to the concept of morality too: the traditional concern for being scrupulous (seen more often among the people in the rooster coop) is forsaken to make space for opportunism and exploitation without sensitivity towards fellow beings. Balram's growth from belonging to the rooster coop to being an entrepreneur is quite antithetical to the progress of his moral degeneration-his entry into Delhi, "a city where civilization can appear and disappear within five minutes” (Adiga 281), materializes with his ditching of Ram Persad, a fellow driver who he knows to be a better driver with an acute need for the job. Though a part of him "wanted to get up and apologize to him right there and say, ... You never did anything to burt me. Forgive me, brother," the ambitious entrepreneur in him subdues this feeling as he "turned to the other side, farted and went back to sleep" (Adiga 110). This slightly sensitive entrepreneur is much colder when he forsakes his family members for his transformation achieved through the murder of his master. At a later stage, as a successful entrepreneur in the Light, the protagonist is devoid of any concern for any human beings, and is proud of this lack of sentiment: "I'd fix that assistant commissioner of police at once. I'd put him on a bicycle and have Asif knock him over with the Qualis” (Adiga 320). The materialistic rise of Balram thus contrasts with his moral descent, which is much in correspondence with the traits of neocapitalism. 
The ultimate product of this interplay of "rise and fall" is an amoral, proud but successful entrepreneur. However, Balram's success is complete only for the outer world and not for Balram himself: he is little at ease with himself. His persona, Ashok Sharma, is confident in tone, proud of his possessions and sure of his effectiveness and manipulative skills—his "prophetic" words to the Chinese Premier about his own future are evidence enough for his hauteur: "I love my start-up-this chandelier, this silver laptop and these twenty six Toyota Qualises-but honestly, I'll get bored of it sooner or later. I'm a first-gear man ... you see, I am always a man who sees 'tomorrow' when others see 'today'” (Adiga 319).

All the same, there are sufficient ruptures in the narration that allow for some glimpses of Balram the boy from Laxmangarh within Ashok Sharma, the entrepreneur-the intermittent suggestions of guilt, the fear of the Rooster Coop and his sympathies with the people in the Darkness. Though the intention of murdering Ashok was conceived much earlier, there were hesitations on the part of Balram on course to the execution, showing that he had not broken away from the values of his class. When Kusum sends Dharam to him to be trained in his lines, Balram, in a kind of relief, says, "this boy's arrival has saved me from murder." Suggesting another hint of guilt in him are his ponderings over the consequences of his murder of Ashok on his family members: "One day, I know, Dharam, this boy who is drinking my milk and eating my ice-cream in big bowls, will ask me, couldn't you have spared my mother? Couldn't you have written to her telling her to escape in time? And then I'll have to come up with an answer" (Adiga 316). Balram's promotions from being a cleaner to being a driver to becoming an entrepreneur are nothing but his constant efforts to escape the Coop. In fact, the narrator refers repeatedly to the binding Coop, indicating his fear of being trapped in it: "Here in India we have no dictatorship. No secret police. That's because we have the Coop" (Adiga 175). The protagonist cherishes a deep rooted aversion to the willing submission of the rooster to the unscrupulous ploys of the rich. His success lies, to a great extent in identifying and escaping the coop whenever the circumstances demanded it of him. Noticeably, on the threshold of his freedom, just before he boards a train to a new life, Balram was tested for a moment by a fortune telling machine's prophetic lines trying to hoodwink him- "Respect for the law is the first command of the gods." Evidently, Balram could see through the ploy as he says: "the sirens of the coop were ringing-its wheels turning-its red light flashing! A rooster was escaping from the coop!" (Adiga 248).

However, there is one act of Balram in his upward mobility that goes against the grain-his relationship with Dharam, the boy from his family. No matter how earnestly Balram strives to distance himself from 
the "coop," he is unable to shed its link to him in the form of Dharam. Evidently, Balram is yet to get himself completely transformed inside the persona of Ashok Sharma. "He nurtures his only relative on earth, the young 'Dharam'” (Molly 78). Curiously, his attempt to escape the coop goes along with his covert sympathies for the people in the darkness as well. "These people were building homes for the rich, but they lived in tents ... it was even worse than Laxmangarh" (Adiga 260). The very tone of narration in spite of all its deliberate "display," takes the side of poor India which the Chinese Premier would not get a chance to observe.

The ruptures in the narration do show the trails of Balram of the Coop in Ashok Sharma. In fact, this creates within him a sense of incompleteness, a sense of "half-bakedness." Nevertheless, the persona cannot afford to allow these traces of the Darkness to surface. Hence, the narrator, in addressing the Chinese Premier, assumes a personality of heightened importance and a shrewd smugness, which only help him to cover his own insufficiencies. Balram's justification for the act of murder for assuring himself of what it means not to be a servant— - just for a day, just for an hour, just for a minute" (Adiga 321) is an attempt by the "free man" of the neo-capitalist world to overshadow the visitations of the darkness lurking within. His dismissive tone, his cynical attitude to Indian society, his obsession with the elite way of life symbolized by the chandeliers in his toilet, his preference to "buy girls . . . in five-star hotels," the Macintosh computer, his coming to terms with "this India" of choices, leaving out "that India" devoid of choice are all his attempts to find some solace in the midst of the chaos created by the neo-capitalist forces. In fact, the very act of choosing an upper caste name "Sharma" for "Halwai" is an attempt by the margin to merge with the centre. But it should be noted that the measures the protagonist resorts to, including the adoption of the name Sharma, are too feeble to fuse the fringe with the core. His desperate efforts to establish himself as part of the mainstream alienate him further away from the "centre" within the persona of Ashok Sharma as he retains in him the traces of Balram. The echoes of his roots never allow the protagonist to have a sole identity either of a "Sharma" or of a "Halwai" in the neo-capitalist world. Even at the height of his success "Ashok Sharma" shudders at the thought of being identified as "Balram Halwai." As he says:

At such moments, I look up at this chandelier, and I just want to throw my hands up and holler, so loudly that my voice would carry over the phones in the call centre rooms all the way to the people in America: I've made it! I've broken out of the coop! But at other times someone in the street calls out, "Balram," and I turn my head and think, I've given myself away. (Adiga 320) 
The entire materialistic ascendancy of "Halwai" is at best a realization of his aspirations in the form of "Sharma." But in the process, he sacrifices the aspirations of the marginalized that anticipate a possible economic transformation in "the world of choices." The deep aversion of the protagonist to the rooster coop emerges from his ultimate recognition that what is required in the changed world is status quo rather than economic empowerment. Ironically, the narrative dominance of "Sharma" subjugates "Halwai" leaving him meek and marginalized. Had the protagonist retained the strains of marginality of "Halwai" shown through his roles as shrewd driver, disgruntled servant, and a voyeuristic observer of the seductive cosmopolitan world, he would have succeeded in creating a space for the representative individual voice of the marginalized.

Startling though it is, even "Sharma" is not as "free" and "potent" as he claims to be. Only, "Sharma" is unaware that he himself is prey in the cobweb of materialist allurement. The hauteur and the cynical strain of triumph in the narrative is a manifestation of "Sharma" being the neocapitalist forces' naïve spokesperson, incapable of making "a conscientious choice" in "the world of choices." Through "Sharma," the whole idea of "marginalization" gets redefined in economic terms where one's ability to exploit the opportunities to one's favour is seen as the key to break away from the rooster coop. While perceiving himself as deprived, and continuing to climb the ladder, the protagonist sees only opportunities for the self and runs away from the realities of the marginalized. Thus, the neo-capitalist world insidiously sucks up the collective consciousness of the individual and reduces him to a mere self-absorbed entity. It is easily discernible that this entity is incapable of identifying the centres of the new forces. Instead, the protagonist seems to be under the illusion of being the centre and revels at the thought of reversing the power structure. In fact, the neo-capitalist forces are so clinical in the execution of their coup that the protagonist perceives "marginalization" as the natural fallout of the failure of the marginalized rather than as a systemic insufficiency. The execution of the neo-capitalist coup creates a new persona within the protagonist for whom the binaries of "the centre" and "the margin" cease to exist.

True though it is that the gulf between the margin and the centre becomes indistinguishable for "Sharma," he is engulfed in a world of myriad voices and make-believe. In fact, the changed world presents strains of discordant voices: there are echoes of Halwai and the scruples of his conventional society, there is the resonance of a transitional society confused by its value system and there is the voice of the new persona of the protagonist "Sharma" with its obsession with the "self," heard in the various junctures of the narration. Among these, the voice of the new persona seems 
the most vociferous and self-assured as the persona fallaciously thinks that he lives in a symbiotic world of economic vortex where he needs to assert his position through a voice louder than that of the rest. However, in his attempt to make his voice heard in a world of cacophonic voices, the new persona lacks identity and peculiarity. It is certainly not a simple, one dimensional and triumphant voice of an achiever who is able to break the coop and revel at the reversal of fortune. Neither is it a representative voice of the suppressed class turning the table on its oppressor by using the opportunities offered by the global market. Clearly, the discord in the changing notes is brought about by the forces that changed the world he lives in-a neo-capitalist world. The whole process of Balram turning into Ashok Sharma is a neo-capitalist coup.

\section{WORKS CITED}

Adiga, Aravind. The White Tiger. New Delhi: Harper, 2008. Print.

Ceaser, Ed. "News Review Interview: Aravind Adiga." The Sunday Times 19 Oct. 2008. Web. 25 Oct. 2011.

Mattin, David. "The White Tiger, by Aravind Adiga." Rev. of The White Tiger, by Aravind Adiga. The Independent 11 May 2008. Web. 23 Oct. 2011.

Molly, Joseph M. “The Great Indian Rooster Coop': A Postcolonial Entry into Aravind Adiga's The White Tiger." Littcrit 35.1-2 (2009): 76-80. Print.

Singh, Krishna. "Aravind Adiga's The White Tiger: The Voice of Underclass-A Postcolonial Dialectics." Journal of Literature, Culture and Media Studies 1.2 (2009): 98-112. Print.

Taras, Ray. "Review: Aravind Adiga's 'The White Tiger." Campaign for the American Reader 29 May 2008. Web. 26 Oct. 2011. 